\section{References}

Bendix-Almgreen, S. E., Clack, J. A. \& Olsen, H. 1988: Upper Devonian and Upper Permian vertebrates collected in 1987 around Kejser Franz Joseph Fjord, central East Greenland. Rapp. Grønlands geol. Unders. 140, 95-102.

Bütler, H. 1954: Die Stratigraphische Gliederung der Mitteldevonischen Serien im Gebiete von Kap Franklin an Kejser Franz Joseph Fjord in Zentral-Ostgrönland. Meddr Grønland 116(7), $126 \mathrm{pp}$.

Bütler, H. 1957: Beobachtungen an der Hauptbruchzone der Küste von Zentral-Ostgrönland. Meddr Grønland 160(1), 79 pp.

Bütler, H. 1959: Das Old Red-Gebiet am Moskusoksefjord. Meddr Grønland 160(5), 188 pp.

Friend, P. F., Alexander-Marrack, P. D., Allen, K. C., Nicholson, J. \& Yeats, A. K. 1983: Devonian sediments of East Greenland VI: review of results. Meddr Grønland 206(6), 96 pp.

Jarvik, E. 1961: Devonian vertebrates. (East Greenland). In
Raasch, G. O. (edit.) Geology of the Arctic 1, 197-204. Toronto U.P.

Koch, L. \& Haller, J. 1971: Geological map of East Greenland $72^{\circ}-76^{\circ}$ N. Lat. (1:250 000) Meddr Grønland 183, 26 pp.

Marcussen, C., Christiansen, F. G., Larsen, P.-H., Olsen, H., Piasecki, S., Stemmerik, L., Bojesen-Koefoed, J., Jepsen, H. F., Nøhr-Hansen, H. 1987: Studies of the onshore hydrocarbon potential in East Greenland 1986-87: fieldwork from $72^{\circ}$ to $74^{\circ}$ N. Rapp. Grønlands geol. Unders. 135, 72-81.

Marcussen, C., Larsen, P.-H., Nøhr-Hansen, H., Olsen, H., Piasecki, S. \& Stemmerik, L. 1988: Studies of the onshore hydrocarbon potential in East Greenland 1986-87: field work from $73^{\circ}$ to $76^{\circ} \mathrm{N}$. Rapp. Grønlands geol. Unders. 140, 89-95.

Säve-Söderbergh, G. 1934: Further contributions to the Devonian stratigraphy of East Greenland. II. Investigations on Gauss Peninsula. Meddr Grønland 96(2), 74 pp.

Stemmerik, L. 1988: A preliminary study of the porosity and permeability of limestones and sandstones in the Jameson Land area, central East Greenland Rapp. Gronlands geol. Unders. 140, 80-84.
P. H.-L.\&H.O., Grønlands Geologiske Undersøgelse, $\emptyset$ ster Voldgade 10, $D K-1350$ Kфbenhavn $K$, Danmark.
F. O. R.,

Danmarks Geologiske Undersøgelse, Thoravej 8 , DK-2400 København NV, Danmark.
U. G. W.

Geologisk Centralinstitut, $\emptyset$ ster Voldgade 10, $D K \cdot 1350$ Kobenhavn $K$, Danmark.

\title{
Geological investigations of Prinsesse Ingeborg Halvø, eastern North Greenland
}

\author{
Eckart Håkansson, Lena Madsen and Stig A. Schack Pedersen
}

Station Nord in Kronprins Christian Land has been the gateway to North Greenland for most geologists since the 1950s, yet little is actually known about the geology of Prinsesse Ingeborg Halvø, the low, barren stretch of land which surrounds the station. A major objective of the Ingeborg Expedition in July and August 1988 was to fill this gap by following up work initiated during the GGU expedition in 1980 (Håkansson et al., 1981).

With a central position in the on-shore part of the Wandel Hav Strike-Slip Mobile Belt (cf. Håkansson \& Pedersen, 1982), Prinsesse Ingeborg Halvø constitutes an essential element in structural correlation across eastern North Greenland. It is further located at the hinge between the North Greenland - Svalbard Rift Basin and the East Greenland - West Norway Rift Basin, which governed deposition in the early phases of the Wandel Sea Basin (cf. Håkansson \& Stemmerik, in press), thus enhancing the significance of this area for the understanding of the regional geology. Investigation of the unique, partly silicified bryozoan fauna known to abound from previous visits was an additional topic for the expedition (cf. Madsen \& Håkansson, in press).

Transport of samples and equipment within the area was by three-wheeled Honda motorcycles equipped with balloon-tires and a trailer, in much the same way as during an expedition by two of the authors to Kilen in 1985. This type of ground transport provides an adequate logistic background for smaller parties, provided the terrain is suitable and the equipment up to standard. However, the use of back-up units is advisable.

\section{Physiography}

Prinsesse Ingeborg Halvø (fig. 1) has a subdued topography with altitudes scarcely exceeding $150 \mathrm{~m}$ above sea level. The interior is made up of rolling plains draped by a veneer of soliflucted till, while the coastal 


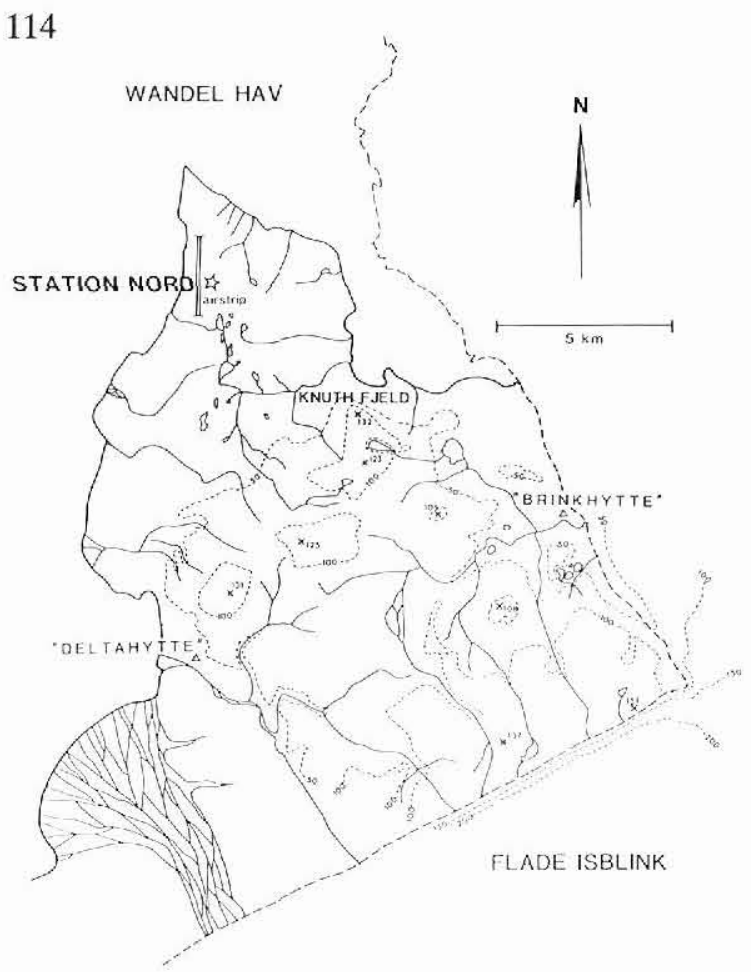

Fig. 1. Map of Prinsesse Ingeborg Halvø.

parts, especially to the north and east, are fringed by wide beach-ridge plains.

Glacigene sediments are widespread, while traces of glacial erosion and striations are absent. This is due to the relative softness of the pre-Quaternary substrate, and the landscapes are therefore to a large extent an expression of recent geomorphological processes. Most important are the deeply incised stream beds which commonly provide the only decent exposures of bedrock geology.

\section{Upper Palaeozoic lithology and fauna}

Three suites of sedimentary rocks were distinguished during the field work but, due to the structural complexity, the pronounced lateral variation in thickness and the repetitive character of the strata, their stratigraphic interrelationship has yet to be fully clarified. Here they are briefly characterized in assumed statigraphic order (fig. 2).

Fig. 2. Composite lithological section. Units I - III are shown in assumed stratigraphic order, with structural data omitted: 1 . Algal lamination; 2. Fusulinid foraminifers; 3 . Sponges; 4. Solitary corals; 5 . Colonial corals; 6. Gastropods; 7. Brachiopods; 8 . Fenestrate bryozoans; 9 . Trepostome bryozoans; 10. Crinoids; 11. Phycosiphon; 12. Zoophycos; 13. Slumping.

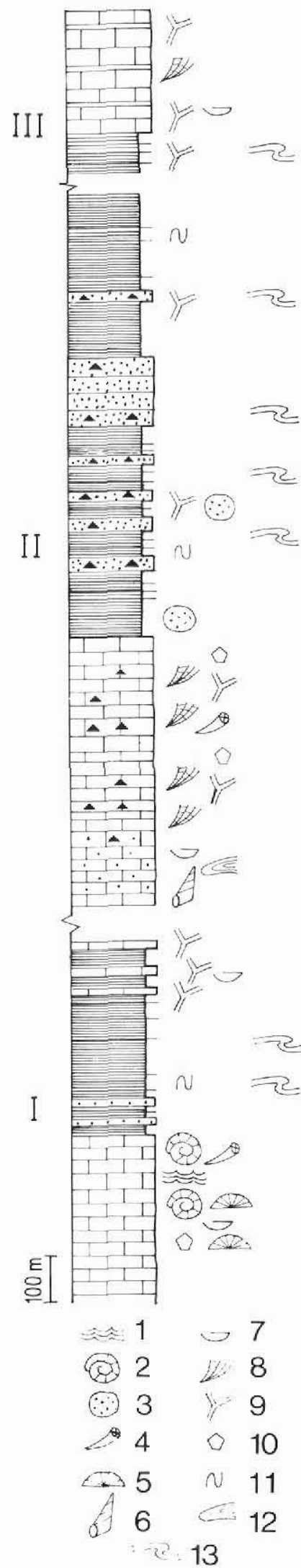


I. The lower sequence is comparatively well exposed in the central and eastern part of the area where it is consistently disturbed by a large number of partly bedparallel thrusts and faults. Its lower part is almost exclusively made up by light to dark grey carbonates which accumulated on what appears to be a shallow marine platform. The fairly rich fauna is dominated by both solitary and colonial rugose corals, tabulate corals, and productid brachiopods, in addition to locally abundant fusulinid foraminifers. The platform was drowned by black mud which, in its initial part, contains a fair proportion of extensively chertified siliciclastic beds and subordinate calcarenites. Gradually, the proportion of chert beds decreases, leaving only fine grained, yellow calcarenitic intercalations. These carbonate sands are disturbed by synsedimentary slumping and, at this level, more prominent units of olistostromic conglomerates were also found. From this part of the sequence only trace fossils (including Rhizocorallium, Phycosiphon and Chondrites) were noted. In the higher parts of the sequence the proportion of fine grained calcarenites increases and from these beds a bryozoan fauna dominated by thick, branching trepostomes (notably Dyscritella) was collected. The thickness of this sequence is very difficult to estimate due to severe thrusting; most likely it is more than $500 \mathrm{~m}$. From previous collections of fusulinids it has been established that the carbonate platform initiating the sequence is of Early Permian age, probably belonging to the Rugofusulina arctica Zone (Hảkansson \& Stemmerik, 1984; Stemmerik \& Hảkansson, in press). No further age data are so far available.

II. The middle sequence is exposed in the northern limb of a large syncline east of Station Nord, where approximately $1 \mathrm{~km}$ of strata are exposed to a varying degree. This sequence includes the spectacular silicified bryozoan limestone from the prominent hill known unofficially since the early fifties as 'Knuth Fjeld'. In the lower part this sequence is dominated by fossiliferous carbonates interrupted by a few prominent quartz sandstone beds with Zoophycos and other trace fossils. Thickness variations as well as lateral facies shifts are pronounced. At many levels the fauna is exceptionally rich and totally dominated by diverse and conspicuous bryozoans, notably fenestrates, large branching trepostomes, and Goniocladia, in addition to a few cryptostomes (fig. 3). Usually the fauna includes a noticeable proportion of brachiopods and solitary corals as well. At some levels the limestones are totally dominated by disintegrated crinoid ossicles. The general composition of the fauna and the preservation of even the most fragile bryozoan skeletons leave little doubt that most of these limestones were laid down in a fairly shallow water environment under very quiet conditions. In situ burial of colonies in life position has been noted and at
Fig. 3. Rock-forming bryozoans from the lower half of unit II. The naturally weathered surface reflects the light, differential silicification of most skeletal material at this level. Fairly large fragments of arborescent colonies of trepostome bryozoans are most conspicuous, although the lacelike fragments of fenestrate colonies form an equally important component.

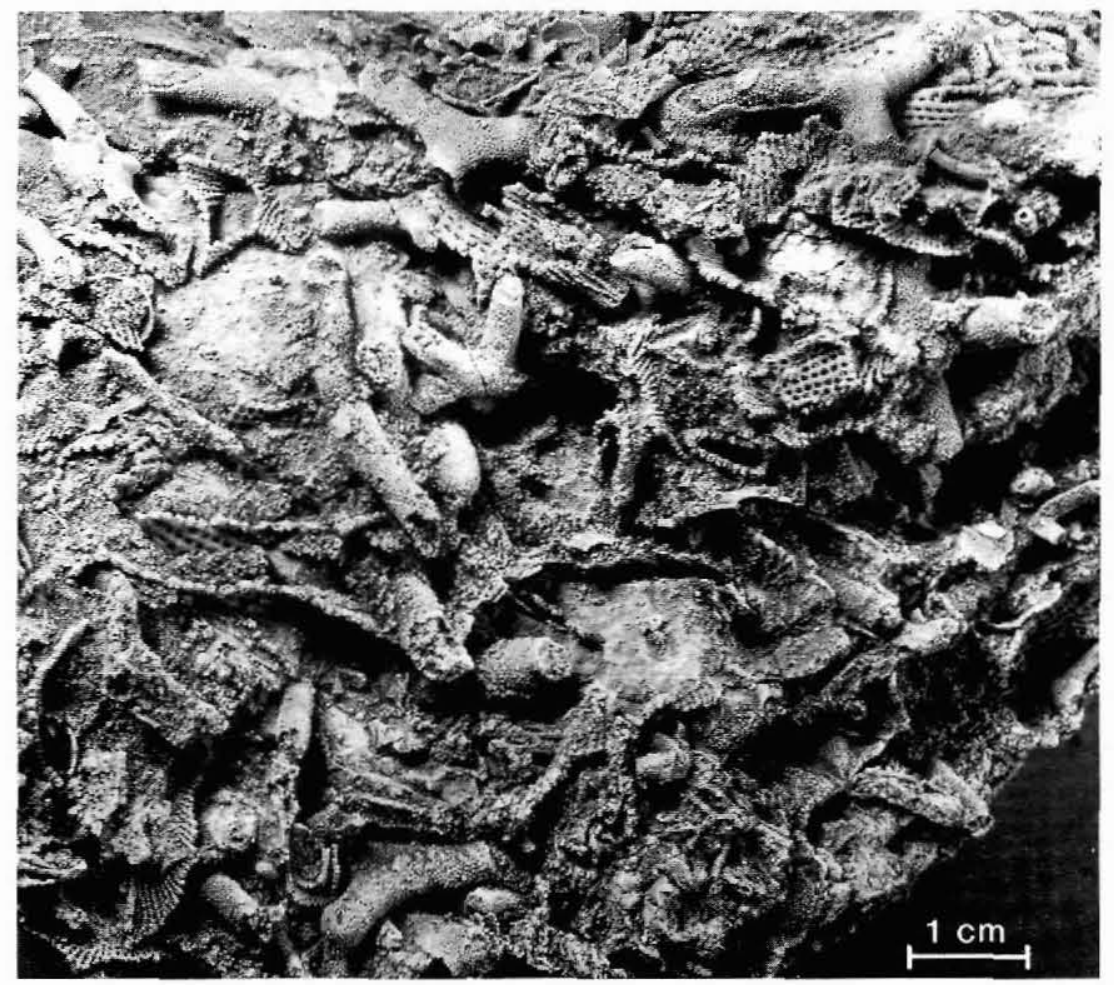


least some of the limestones are likely to represent organic build-ups. Higher in the sequence the carbonates give way to a deeper water, mud-dominated clastic series with varying amounts of orange to yellow weathering fine grained carbonates and coarser grained siliciclastic beds intercalated. These beds are commonly slumped. Trace fossils (including Phycosiphon and Chondrites) are common, whereas a restricted fauna of body fossils is present only locally. In the fine grained carbonates, in particular, the fauna comprises a mixture of trepostome and fenestrate bryozoans and sponges which may be the result of synsedimentary redeposition.

III. The third sequence mainly occupies the southern, very poorly exposed part of the area. Here a muddominated clastic sequence with the same general properties as the upper part of the preceding sequenece is in turn overlain by a series of fairly thin-bedded, richly fossiliferous limestones interbedded with less fossiliferous to almost barren, impure limestones and marly shales. Throughout the sequence the fauna appears similar to that of the preceding sequence, and an overall similarity in depositional environments is probable. The exposed thickness amounts to about $500 \mathrm{~m}$, but it is not known to what extent the two mud sequences overlap.

In addition to the above-mentioned rock types, several severely disturbed units are present in the prominent thrust zones developed in the north-eastern and southern part of the area. Among a suite of partly hydrothermally altered cataclastic rocks of both local and unknown provenance, two types of sediments occur which have preserved most of their original character.

Fine grained fluvial silts and sands with subordinate amounts of high grade coal are present through most of the southern thrust zone; similar coal is very abundant in association with the northern thrust zones, but here it has not been found in situ. Analogous sediments may be found in the Early Carboniferous Sortebakker Formation on the south coast of Holm Land c. $150 \mathrm{~km}$ to the south (Håkansson \& Stemmerik, 1984; Stemmerik \& Håkansson, in press). Coal of lower grade is present in the Paleocene Thyra $\emptyset$ Formation which occupies the areas immediately to the south (Håkansson et al., 1981). Judged from lithological criteria alone, the sequence in Prinsesse Ingeborg Halvø is more similar to the Sortebakker Formation, but no positive evidence of a comparable age exists as yet from Prinsesse Ingeborg Halvø.

Gypsiferous evaporites are abundant, particularly in the southern thrust zone. Comparable evaporites are known from undisturbed sequences in Amdrup Land where they are found in the Moscovian Kap Jungersen and Foldedal Formations (Stemmerik \& Håkansson, in press). However, their age in Prinsesse Ingeborg Halvø has not been established.

The composite sequence recorded from Prinsesse Ingeborg Halvø is about $2 \mathrm{~km}$. The Early Permian age established for the lowermost part of the sequence is the only date available at this time. However, the character of the fauna of even the highest beds demonstrates that the entire sequence was deposited prior to the final disappearance of the major Palaeozoic faunal elements. A Permian age throughout is therefore likely.

The repeated change in facies between shallow water platform carbonates and deeper water clastic muds with widespread slumping indicates unstable conditions in this segment of the Wandel Sea Basin, with at least two major episodes of subsidence in the later part of the Permian. This is in contrast to other parts of the basin and, as pointed out by Håkansson \& Stemmerik (in press), the structural entity of the original Wandel Sea Basin concept can no longer be maintained.

\section{Structural geology}

Five deformation phases are discernible on Prinsesse Ingeborg Halvø, four of which can be ascribed to structural events of regional magnitude and importance (fig. 4). The most conspicuous phase is compressional, thinskinned imbricate thrust fault tectonics leading to a stacking of steep, northerly inclined thrust sheets with a general, E-W to SE-NW regional strike. This deformation is also responsible for the inversion which makes it possible to study the formerly deeply buried sedimentary sequences in this part of the Wandel Hav StrikeSlip Mobile Belt. However, the thrust fault deformation follows three older deformations (D1-D3) and is postdated by Tertiary block faulting along the regional NW-SE striking fault system (D5).

D1: synsedimentary slump folding. Slump folding is particularly well developed in the repeated sequences of black shales with thin, interbedded calcarenitic layers and lenses. The slump folds range in size from interlamellar folds to folded calcarenite lenses and layers with an amplitude of 2-3 m and wave length of 3-7 m. The fold styles are very irregular, but at some levels recumbent, tight to isoclinal folds appear which allow determination of the general slump direction. Monoclinal slope bedding related to the slumping also occurs, with elongation and extensional separation of beds out of sequence. This phase is known only locally, reflecting stepwise subsidence of this part of the Late Palaeozoic carbonate platform through the later parts of the Permian. Traces of a Caledonian phase reported previously 


\begin{tabular}{|c|c|c|c|c|}
\hline $\begin{array}{l}\text { DEFORMATION } \\
\text { ANNOTATION }\end{array}$ & FOLDING & FAULTING AND THRUSTING & FABRIC & $\begin{array}{l}\text { METAMORPHIC } \\
\text { ALTERATION }\end{array}$ \\
\hline$D_{1}$ & $\begin{array}{l}\text { irregular, recumbent } \\
\text { slump folding }\end{array}$ & none & none & none \\
\hline $\mathrm{D}_{2}$ & roll over anticlines & extensional normal listric faults & exfoliation cleavage & $\begin{array}{l}\text { chertification and calcite } \\
\text { mobilization in veins }\end{array}$ \\
\hline$D_{3}$ & none & extensional normal faults & jointing & $\begin{array}{c}\text { ankerite, siderite and haematite } \\
\text { mobilization in veins }\end{array}$ \\
\hline$D_{4}$ & $\begin{array}{l}\text { thrust ramp anticlines } \\
\text { and upright folding }\end{array}$ & $\begin{array}{l}\text { contractional faults, } \\
\text { flat and ramp thrust fault tectonics }\end{array}$ & slaty cleavage & $\begin{array}{l}\text { cataclastic brecciation and } \\
\text { greenschist facies alteration }\end{array}$ \\
\hline$D_{5}$ & none & $\begin{array}{c}\text { block faulting along } \\
\text { NW-SE striking regional faults }\end{array}$ & none & cataclastic brecciation \\
\hline
\end{tabular}

Fig. 4. Schematic summary of the five deformation phases discernible on Prinsesse Ingeborg Halvø.

(Håkansson et al., 1981) have not been substantiated. It appears that the (refolded) large scale slump folding developed locally was the factual background for this assumption, which was further enforced by the rock types found and the flyschoid character of the trace fossils (cf. Håkansson et al., 1981).

D2: extensional normal listric thrust faulting. These thrust faults are developed with steps and steep ramps with offsets of about $10 \mathrm{~m}$. Going down sequence the ramp faults bend into bedding-parallel flats. Duplex structures and horses are common features related to the extensional thrust faulting. Calcite veins and tension gashes occur frequently in the carbonates, and complex development of chertification features in the calcarenites probably indicates that such diagenetic alteration is related to the extensional deformation. An exfoliation cleavage was developed in the black shales during this deformation. D2 represents deformation originating in the Ingeborg Event of the Wandel Hav Strike-Slip Mobile Belt (Pedersen, 1988; Håkansson \& Stemmerik, in press). Outside Prinsesse Ingeborg Halvø the event is well developed in Kilen on the eastern side of Kronprins Christian Land (Håkansson \& Pedersen, unpublished data), whereas precise structural observations are not available from Peary Land (cf. Håkansson \& Pedersen, 1982). Deformation in the Ingeborg Event was the structural background for the Late Jurassic transgressions.
D3: extensional faulting. This extensional deformation is superimposed on the earlier structures. The deformation is characterized by intensive jointing and extensional fracturing. A paragenesis of calcite, ankerite, siderite, and hematite occurs in veins and vugs. The structures are concentrated in the northern and northeastern parts of the peninsula, but minor deformation related to this phase occurs throughout the region. D3 represents deformation originating in the Kilen Event of the Wandel Hav Strike-Slip Mobile Belt (Pedersen, 1988; Håkansson \& Stemmerik, in press). It is well developed in Kilen, but not discernible in Peary Land with the present structural information. Deformation in the Kilen Event led to the formation of the pull-apart basins governing Late Cretaceous deposition across eastern North Greenland (Håkansson \& Pedersen, 1982; Birkelund \& Håkansson, 1983).

D4: compressional thrust faulting. Virtually all of Prinsesse Ingeborg Halv $\emptyset$ has been affected by compressional thrust faulting. The thrust sheets dip steeply (more than $45^{\circ}$ ) towards the north, and ramp and flat geometries show that the general thrust displacement is directed to the south and south-west. The maximum thickness of individual thrust sheets has been measured to $150 \mathrm{~m}$, but minor thrust imbrication and great variation in frameworks and types of duplex structures divide the sheets into smaller segments. With the presence of gypsiferous strata the thrust frequency intensi- 
fies, and cataclastic brecciation also increases towards the gypsiferous cliffs along the major NW-SE trending fault zone at the 'Deltahytte'. Along this zone thrust faulting and related brecciation have been most intensive, with greenschist facies metamorphism developed in the cataclastic breccias. The indicative metamorphic minerals are tremolite in recrystalized, impure limestone, and chlorite and sericite catablasts in fine grained, earthy light green cataclastites. In the gypsum catablastic recrystallization resulted in coarse grained, glass-clear aggregates. Several zones of similar cataclastic brecciation are located along the glacier margin to the north-east and in the stream section north-west of the 'Brinkhytte'; here they are dominated by mylonites and trachymylonites of unknown provenance.

The uppermost thrust sheets, in the northern part of the area, are characterized by open, broad upright folds with a fold axis directed $\mathrm{E}-\mathrm{W}$. The folding is somewhat irregular due to depositional differences in the limestones in particular. In places carbonate recrystallization and calcite-filled fractures and joints have completely obliterated the original bedding of the carbonate rocks.

D4 includes deformational elements of the Kronprins Christian Land Orogeny, the main compressional event and the final event in the Wandel Hav Strike-Slip Mobile Belt (Pedersen, 1988; Håkansson \& Stemmerik, in press); it thus corresponds to F2 in the account by Håkansson et al. (1981). The orogeny predates the Late Paleocene Thyra $\emptyset$ Formation and, as reviewed by Håkansson (1988), this event was essentially concluded in the Late Cretaceous.

D5: Tertiary block faulting. The faults activated in the Tertiary are concentrated in the delta region bordering Prinsesse Ingeborg Halvø to the south. Lower Tertiary sediments in the fault blocks to the south-west and Upper Palaeozoic strata in the blocks to the north-east indicate an uplift of northerly blocks relative to the downfaulted terrain to the south.

E. H.\& L. M., Inst. for Historisk Geologi og Palacontologi, Oster Voldgade 10, DK-1350 København $K$, Danmark.
Acknowledgements. The expedition was supported by grants from the Carlsberg Foundation. The Geological Survey of Greenland supplied most of the equipment, and the Royal Danish Air Force provided logistic support. Svend Funder and Per Mølgaard, who undertook Quaternary and biological investigations, are thanked for their participation in solving the mechanical problems developing in the course of expedition. Finally the personnel at Station Nord, most notably the station leader, Jan Pedersen, are thanked for invaluable contributions to secure the continuous functioning of our mechanical equipment.

\section{References}

Birkelund, T. \& Håkansson, E. 1983: The Cretaceous of North Greenland - a stratigraphic and biogeographical analysis. Zitteliana 10, 7-25.

Hăkansson, E. 1988: Did Tertiary compressional tectonics take place in North Greenland? Summary of the evidence. Norsk Polarinst. Rapportserie 46, 101-104.

Håkansson, E., Heinberg, C. \& Stemmerik, L. 1981: The Wandel Sea Basin from Holm Land to Lockwood $\varnothing$, eastern North Greenland. Rapp. Grønlands geol. Unders. 106, 47-63.

Håkansson, E. \& Pedersen, S. A. S. 1982: Late Paleozoic to Tertiary tectonic evolution of the continental margin in North Greenland. Mem. Can. Soc. Petrol. Geol. 8, 331-348.

Håkansson, E. \& Stemmerik, L. 1984: Wandel Sea Basin-The North Greenland equivalent to Svalbard and the Barents Shelf. In Spencer, A. M. et al. (edit.) Petroleum geology of the North European margin, 97-107. Norwegian Petroleum Society: Trotman \& Graham.

Håkansson, E. \& Stemmerik, L. in press: Wandel Sea Basin a new synthesis of the Late Paleozoic to Tertiary accumulation in North Greenland. Geology.

Madsen, L. \& Håkansson, E. in press: Late Palaeozoic bryozoans from the Wandel Sea Basin, North Greenland. Rapp. Gronlands geol. Unders.

Pedersen, S. A. S. 1988: Model of structural events in the Late Mesozoic platform break-up between Greenland and Svalbard. Norsk Polarinstitutt Rapportserie 46, 99-100.

Stemmerik, L. \& Håkansson, E. in press: Stratigraphy and depositional history of the Upper Palaeozoic and Triassic sediments in the Wandel Sea Basin, eastern North Greenland. Rapp. Grønlands geol. Unders.
S. A. S. P., Danmarks Geologiske Undersøgelse, Thoravej 8 , DK-2400 København NV Danmark. 